\title{
Thinking about gender, thinking about a common space of observation and discussion of the work activity of the other: the case of bus drivers
}

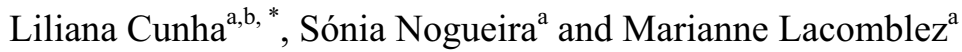 \\ ${ }^{\mathrm{a}}$ Centro de Psicologia da Universidade do Porto, Universidade do Porto, Rua Alfredo Allen, 4200-135 Porto, \\ Portugal \\ ${ }^{\mathrm{b}}$ Universidade Católica Portuguesa, Rua Diogo Botelho 1327, 4169-005 Porto, Portugal
}

\begin{abstract}
The work activity of urban bus drivers is held in the public space and characterized by a constant vigilance, but the moments of observation the colleagues' work are scarce. This fact results in a paradox - it is a work activity that is more visible to "outsiders" than to "insiders" - which has an important impact on the debate of the work activity from a perspective of gender and the women's work in a predominantly male context. Ergonomic analysis of work and semi-structured interviews were conducted with 32 urban public transport drivers, 16 women and 16 men. The results reveal the lack of conditions for the drivers' knowledge of the activity of another, especially when that other is a woman - while men attribute characteristics to women based on gender stereotypes and an extension of their role in the private sphere, women relate them with the need to prove their competence and be recognized. It is proposed the development, in the context of training, of a space for debate and knowledge of the activity of the other and for the creation of conditions for another integration of women in the profession and for another visibility of their work.
\end{abstract}

Keywords: solitary activity, female drivers, visibility, training

\section{Introduction}

The study of the work activity of urban public transport drivers driven by gender has contributed to the rise of new issues regarding the knowledge of the sector $[1,5]$. For many years in Portugal, this profession was reserved for men and only recently it started to integrate women, with the feminization process still ongoing. Some characteristics of the activity, namely that of being a solitary activity, undertaken outside the company's facilities, attribute some specificities to the life of the work group, which has few opportunities for sharing and collective reflection on their own work and the others'. This also has influence on the knowledge that colleagues have about the women's work and how they are seen and integrated. This paper presents a reflection on how the training, as a space and time for a formal meeting of the work group, can make a contribution to a greater understanding of the work activity of all drivers and to another integration of women in the profession.

*Corresponding author. E-mail: 1cunha@porto.ucp.pt 


\section{The work activity of urban public transport drivers}

One of the specific features of the work activity of drivers of public road transport of passengers is related to the fact that it is held in the public space. Even in situations when there are defined exclusive traffic routes to the bus, this circulation is done in a space that "belongs" to everyone and in this sense, always interacts with the dynamic evolution of its constraints.

Elements involved in the drivers' work activity are of various kinds and they have to manage them in order to meet the goals of the company and customers (the organization of working time, the frequency specified for the bus line, etc.), but also their own interests (particularly in the management of their work activity and the preservation of their own health). These elements can be distinguished into two groups: those relating to the vehicles and their interior, including passengers, and those that relate to the outside, external interferences, necessarily variable, such as the characteristics of the route (in terms of bus stops or the state of the road), other drivers, pedestrians $[1,2]$.

On the one hand, the performance of the drivers' work activity, which is held in the public space and not in the company, before passengers, other drivers and pedestrians, results in a permanent vigilance of their work, yet limited to the driving task. On the other hand, a look from inside the industry reveals that it is expected that this activity is not observed by fellow drivers. This is justified by the principle of compliance with the frequency of transport services, which implies the non-circulation of two buses simultaneously with the same origin and destination, in a certain bus line. In fact, drivers manage and regulate their activity, dealing with situations of over demanding, customers, traffic and other drivers, and always trying to meet the schedule for this principle to be respected. The encounter with other drivers in the public space is common, especially when they cross in different directions, but it is still limited in time: they just greet each other and sometimes exchange information, timetables, tickets or "pocket money". Similarly, the variable place of start and end of services with schedules defined by the minute that rarely coincide also justifies the scarce moments of contact between them.

The lack of informal moments of encounter has "influence on the representations (individual and collective) that workers have on the work situations and the competence of its colleagues" $[3$, p. 125 , free translation). This lack of collective moments between colleagues, which prevents a real sharing and a greater knowledge of the activity of the other, may raise some interesting reflections if seen from a perspective of gender and the invisibility that women's work activity often is subject to.

\section{Women's work: various types of (in) visibility}

The reference to the visibility or invisibility of women's work may have different meanings.

The real work of women and the constraints associated with it are more difficult to frame, namely in terms of health - considering the traditional representations of female employment, which assume an almost inexistence of professional risks - or in terms of the dual responsibility (which is reflected in a double work) at the professional and family level, in particular, in what regards the articulation of the demands of a paid work in a professional context and another work, unpaid, in the family and domestic context [4, 8].

The consideration of gender in studies of the working situations and contexts appears to contribute effectively to unravel what was likely to be invisible, discussions, constraints and challenges that women face [1]. For women who have a typically male profession, there is an additional challenge: to integrate a profession where even today, often they are seen as "transgressive", since they adopt behaviors "not so feminine" - to drive, to work "outside" when it is expected that women have a work activity on the "inside", to work "among" of men and interact with them as equals $[6,7]$. For these reasons, in the predominantly male contexts in feminization process, there is another kind of visibility - women are more visible because they occupy a minority position and are constantly under the gaze and "surveillance" of the male colleagues.

When referring to women bus drivers, this aspect is particularly interesting. It is indeed a solitary activity and, in this sense, barely visible to colleagues, but with a visibility produced by the dynamics that characterizes traditionally male contexts.

In other words, this paradox, which holds that, at least apparently, this activity is more visible to "outsiders" than to "insiders", it does have a major impact when discussing the work activity from the perspective of gender: since it is a typically male activity, what is the point of view of male drivers on the specificity of the work activity for women? Do women 
drivers know and recognize this specificity? In the absence of an observation of the work activity of another in real working conditions, what supports and legitimizes those ideas? These are the questions that this paper intends to give answer to.

\section{Methodology}

Consistent with the scientific tradition of the work ergonomics, an ergonomic analysis of the work of drivers was made, in order to better know and understand their work activity, the conditions in which it is undertaken and the constraints that they face. The focus has been on the observation and registration of the verbalizations of drivers in the course of their work (registration "paper and pencil"), in an exploratory perspective. The observations were made with the knowledge of the participants, according to their availability and took, approximately, 470 hours.

Semi-structured interviews with participants were also conducted at the companies' facilities, outside the working time and space of drivers, audio taped and transcribed immediately after its completion. They had an average duration of 50 minutes and included topics such as career paths, motivations for the choice of the profession of driver, the initial training, the conditions and characteristics of the work, past and present, with particular emphasis on schedules, labor relations, future prospects, and gender issues. However, in this paper, there will be mainly presented the data that result from these interviews and relate to the gender dimension, such as the characteristics associated with women in a typically male profession, gender stereotypes, and the differences that the drivers identify between men and women in the work activity.

\subsection{Participants}

The sample used in this study consists of 32 drivers - 16 men and 16 women - from two urban public transport companies. Access to participants was facilitated by the companies, who were asked to consent to the study, and the drivers participation was voluntary.

The average age of participants is 35 years old (M $=34.81, \mathrm{SD}=4.21)$ and 6 years of seniority in the profession $(\mathrm{M}=5.50, \mathrm{SD}=3.69)$. Men have an average age of 34 years $(\mathrm{M}=34.19, \mathrm{SD}=4.29)$ and an average seniority of 6 years $(\mathrm{M}=5.81, \mathrm{SD}=4.05)$. Women have on average 35 years of age $(\mathrm{M}=35.44$,
$\mathrm{SD}=6.54)$ and 5 years of seniority $(\mathrm{M}=5.19, \mathrm{SD}=$ $3.39)$.

\section{Results and discussion}

This research confirmed that this work activity is a solitary activity, despite being held in the public space, and thus being under constant surveillance: drivers effectively report that they have little contact with peers, in a work activity that is performed, simultaneously, in the midst of many people and in isolation.

Thus, the provision of service outside of the facilities of the company and the solitary work are responsible for the scarce opportunities for observing the work activity of another. For all this, the role of the work group as a space for sharing everyday work situations and recognition by their peers often lack in this work activity. This seems to have an even more marked impact on employment of women and the knowledge and in the recognition of their work. In fact, in this context, the lack of knowledge is even more pronounced in what concerns the specificities that characterize the work of women.

The characteristics that are attributed to women appear as an extension of their role in the private sphere - the role of "caregiver", "more sensitive in interpersonal relations", "more patient," "sweet," "delicate" - and not as part of their identity as professionals.

The following interview excerpts reflect this allocation of features "naturally" feminine:

"... they are much stronger at a psychological level, but much more. (...) A woman can handle a crying child there, "What ails you, my son?", we are like "Go outside and you'll see how it entertains." Women have that patience, they have more tact"... (Man, driver for 11 years, 34 years old).

"[The differences between men and women] may, perhaps, be related to the relationship with passengers (...) women are sweeter ..." (Man, driver for 6 months, 41 years old).

Thus, men end up not considering that the characteristics that they perceive may be work-related, as a response of women to their situation in the context in which they work. Nevertheless, women drivers assume that these characteristics which are recognized in the work context are due not to intrinsic characteristics common to all women but, precisely, to the need to protect themselves against possible criticisms to the service provided, that result from the fact that 
they are a minority in a "world of men." A driver explains this as follows:

\begin{abstract}
"The woman herself is more careful (...) Don't tell me that women are more sensitive to the elderly, with young children, that is a lie. (...) Women, as they always have to show what they're worth, they know they can't make a mistake because otherwise everyone will discuss and they will be cause for speaking for everyone, they try to avoid as much as they can for something to happen (...) So, she is more careful in everything: in driving, with the bus, away from the holes, because she knows that if she putts a wheel in a hole, she will be criticized by passengers (...). It is not because she is naturally careful, that maternal image. Is it because of the commentaries (...) people, colleagues... we begin to have that defense as if to say "I'm here, I draw the look of you all and since you have to look, at least do not comment, I will not give you reason to comment" (Woman, driver for 10 years, 46 years old).
\end{abstract}

As this excerpt demonstrates, women end up rejecting these "labels". Indeed, these individual strategies, and that many female drivers think is just theirs, turn out to be common to many them. Another woman says that "women are ashamed" to adopt certain behaviors, easily adopted by men, revealing a greater effort to demonstrate their competence and ensure that there is no remark to be made to their work.

In fact, the need to prove their competence and show they deserve their place in the profession are not exhausted in the early days of integration. Women have to prove it every day and the attention to their own behaviors and the attempt to achieve recognition of their place should be kept throughout their career.

Thus the attribution of characteristics to women is based on stereotypes, despite what they do to prove that they are equal to men. In terms of performance of the activity itself, the analysis of the activity showed no difference between men and women in the effective completion of work, even if they are exposed to different conditions and constraints. This confirms that, as was also found by Rodrigues [6], the idea that women are not able to meet requirements of the profession is not justified, though not everyone thinks this way:

"Women are... the best we had left, she was born with the gift of

driving. These just drive. They do not perform as well as men (...) They do enough, they drive but they lack that savvy. "(Man, driver for 12 years, 34 years old).
Despite the double attempt of women - to prove their own competence and their place in the work group and also to prove that women can be drivers, facing the stereotypes of the profession who question the performance of women and value that of men [6] - this is not identified and therefore not recognized by men. The behavior of women appears to be associated with intrinsic characteristics, "naturally feminine" and their efforts are unnoticed, "invisible" among colleagues and other actors.

The use of strategies that enable women to change the stereotypical image of the profession and be recognized as professionals as competent as men [7] has its effectiveness diminished in a work activity where the observation and awareness of another's work are reduced. And this lack of knowledge that male drivers have on the work activity of women shows that the entry of women into the profession is not in itself a condition of transformation of the dominant male representations in what regards their performance and their contribution to the development of the work activity. For women drivers, the absence of a space for discussion of their own strategies is mainly due to the characteristics of their own work activity, but nevertheless is also related to its minority position in the profession and to the difficulties encountered in the relationship between men and women. According to Scheller [7], "the lack of a space for discussion where it becomes expressible and aware of what lies beneath the individual strategies" may even lead them to abandon the profession (p.100, translation). In the case of drivers studied, the difficulty of creating a space where they can share and uphold the truths that were discovered along their experience in the profession, ultimately presents itself as a source of suffering for women.

In a work activity where informal collective moments are scarce or even inexistent, the creation of formal spaces and moments of sharing is likely to help overcome this obstacle to the recognition of women's work and their competence as professionals just as capable as men.

Training strongly anchored in the real context of work, in the work activity that drivers actually perform, could present itself as an opportunity to give visibility to what men and women drivers do and that is not their knowledge. It is in the sense of the existence of common moments of visibility of the other's work activity that the advantage of a training course can be viewed. 


\section{Conclusion}

In the urban bus drivers work activity, the almost non-existent moments of co-presence, observation and peer interaction leads to a lack of knowledge of what entails the work activity of the other. For women, this lack of knowledge leads to an interpretation of the performance and characteristics of women at work based on gender stereotypes - which assume a natural predisposition for the care, kindness, interpersonal relations - and who question the competence in the primary task of the work activity, the driving task and control of a large vehicle. In fact, it is an obstacle to collective recognition of women as competent drivers and as part of the work group, despite their efforts to do so.

In the absence of spontaneous moments of contact, which is a factor of suffering for women, the creation of a formal and common space for observation and discussion of the work activity of the other can present itself as a solution to this situation. Training can serve as a privileged space (or even the only space) for awareness and knowledge of the work activity of the other. It can also create conditions for another integration of women in the profession and for another visibility of women's work and what it reveals on the work activity itself, particularly in aspects that men tend to trivialize. The effective implementation of such action, in order to allow a better understanding of its possible impact can establish itself as one of the next steps in future research in this sector.

\section{References}

[1] J. Castelhano and S. Nogueira, Género e trabalho: o processo de inserção feminina em profissões tradicionalmente masculinas, Research Final Report, Centro de Psicologia da Universidade do Porto, 2011.

[2] L. Cunha, Psicologia do trabalho, análise ergonómica do trabalho e ergologia. Opções, valores e estratégias no trabalho que contributos para outras racionalidades?, Master Dissertation, University of Porto, 2005.

[3] J. Marc, V. Grosbean and M. C. Marsella, Dynamique cognitive et risques psychosociaux: isolement et sentiment d'isolement au travail, Le travail humain, 74 (2011), 107-130.

[4] K. Messing, Compreender o trabalho das mulheres para o transformar: uma investigação/ acção realizada pela Universidade e pelas organizações sindicais do Quebeque, in: Compreender o Trabalho das Mulheres para o Transformar, K. Messing, ed., CITE, Lisboa, 2000, pp. 51-74.

[5] S. Nogueira, Prazer e sofrimento das mulheres motoristas no sector dos transportes rodoviários de passageiros - a dimensão género no estudo das relações entre o trabalho e a saúde, Master Dissertation, University of Porto, 2009.

[6] A.-C. Rodrigues, Des femmes conductrices de poids lourds. Parcours de vie et rapport au métier d'une portion croissante de la main-d'œuvre dans un métier en mutation. Ph.D. Dissertation, Université Paris-Est, 2010.

[7] L. Scheller, Les bus ont-ils un sexe ? Les femmes machinistes : approche psychodynamique de la division sexuelle du travail à la RATP, RATP, Paris, 1996.

[8] L. Vogel, Um contributo do Quebeque para um debate indispensável ao movimento sindical na Europa, in: Compreender o Trabalho das Mulheres para o Transformar, K. Messing, ed., CITE, Lisboa, 2000, pp. 51-74. 